Jurnal Kesehatan Masyarakat

\title{
Factors Affecting Pregnant Women in Preparation of Early Breastfeeding Initiation (IMD) at Grobogan Regencys
}

\author{
Aniestia Yuliana $^{1 \bowtie}$, M. Zen Rahfiludin ${ }^{2}$, Sri Achadi Nugraheni ${ }^{2}$ \\ ${ }^{1}$ Masters in Public Health, Concentration of Health in Mother and Child, Universitas Diponegoro \\ ${ }^{2}$ Faculty of Public Health, Universitas Diponegoro
}

\section{Article Info \\ Article History: \\ Submitted August 2019 \\ Accepted October 2019 \\ Published November 2019 \\ Keywords: \\ Early Breastfeeding \\ Initiation (IMD), IMD \\ Preparation, trust, \\ knowledge, \\ educational background}

DOI

https://doi.org/10.15294/

kemas.v15i2.20547

\begin{abstract}
Exclusive breastfeeding will be realized if mother start implementing Early Breastfeeding Initiation (IMD) program. The purpose of this study is to investigate factors influencing pregnant women in preparation for early breastfeeding initiation (IMD) in Grobogan regency. Study method is quantitative with cross-sectional design. Total population is 716 pregnant women with minimal of 85 sample after calculations. To anticipate drop out, 100 samples will be collected. Independent variable is the factors influencing preparation of IMD in pregnant women and dependent variable is preparation of Early Breastfeeding Initiation (IMD). Data was analyzed using multiple logistic regression. The analysis showed no significant relation between factors such as education, knowledge, attitudes, breastfeeding experience, husband/family support, participation in classes of pregnant women, the role of health workers with preparation for IMD. In contrast, the variable trust had a significance value of $0.001<0.05$. We conclude that IMD preparation of pregnant women is most influenced by trust.
\end{abstract}

\section{Introduction}

Infant mortality rate (IMR) in Indonesia according to the Indonesian Health Demographic Survey (SDKI) in 2012 remained high at 32 per 1,000 live births with toddler mortality rate of 40 per 1,000 live births (Indonesian Health Profile, 2015). IMR in Indonesia is still high compared to other neighboring countries, such as Malaysia and Singapore, which have under 10 deaths per 1,000 live births. Infant mortality is a sensitive indicator to measure health and development status of a country. The high infant mortality at the age of up to one year shows the low quality of health sector in a certain nation.

IMR of Central Java Province in 2016 was 99.9 per 1,000 live births (5445 cases) and in 2017 there were 2182 mortality cases (Health Profile, 2016). Efforts to provide exclusive breastfeeding is one way to meet the challenges and targets of SDGs in reducing
IMR. WHO/UNICEF recommended exclusive breastfeeding until the age of 6 months with Early Breastfeeding Initiation (IMD) program. IMD is an activity that takes place immediately after the baby is born where the mother let the baby actively seek her nipple with direct skin contact to the mother. IMD will keep the baby warm and improve baby sucking reflexes that will increase success chance of exclusive breastfeeding which later on will contribute to reduction of malnutrition prevalence. IMD can also improve infant immune system to prevent various diseases. Baby that is given the opportunity to suckle in the first hour by direct skin contact to the mother's skin, will at least save $22 \%$ of them until age of 28 days. A study in Zhejiang, China states that Asian cultures of breastfeeding will prevent Helicobacter pylori infection and a cohort study from Shanghai stated that breastfeeding can protect mothers from type II diabetes (Liqian Q et al., 2009). 
IMD can reduce postpartum bleeding caused by pressure to placenta and uterus from the baby that crawls over the mother's chest thus stopping the bleeding. (Noer et al, 2011). In the third trimester and late pregnancy, the mother will start preparing for childbirth and breastfeeding, this marks the best time for midwives and health workers to provide comprehensive information regarding practice of IMD and exclusive breastfeeding. Midwives can provide counseling and information to mothers through Maternal and Child Health $(\mathrm{MCH})$ program, which is carried out in conjunction with Antenatal Care (ANC), especially in late pregnancy ANC at third trimester (Bbaale E, 2014; Acharya P \& Khanal V, 2015; MOH RI, 2015). Preparation for IMD can be initiated at the start of pregnancy, such as providing tools for IMD, enhancing maternal knowledge about IMD from health workers or other sources. Discovering information about IMD procedures can also be acquired through health workers cadres around the neighborhood or the closest people who already practice IMD, providing family or husband support, improving physical readiness such as health check up, breast care, and diet (Esteves, TMB et al, 2014). Comprehensive preparation for IMD is important because IMD will be initiated in the first hour after baby delivery, at the time when mothers experience fatigue while thorough care is being provided from health workers to both mother and baby. The decision or positive attitude of the mother towards breastfeeding developed during pregnancy is crucial in achieving successful breastfeeding. Mothers who received information about IMD, will discover more about the methods and benefits of IMD itself. Knowledge can be obtained through participation in health education such as classes for pregnant women from government programs, information from social environment, books/magazines/social media. Knowledge and counseling can improve IMD and breastfeeding practice up to 3 months postpartum, if the mother is provided with knowledge and a good attitude towards IMD, commitment will arise from herself to perform IMD. The role of the closest people is necessary in encouraging IMD practices. Positive support from the closest person or family, will prepare mother physically and mentally to be able to carry out IMD. The family will support the mother if the right knowledge about IMD is also provided to them. In the end, counseling matters not only to mothers. In addition, company during the delivery process as a way of emotional support can help mother in IMD. Therefore, it is expected that close families, especially husband, to accompany the mother during labor and IMD.

Example of factors that served as obstacles is lack of the proper knowledge during preparation of IMD that can be observed by various opinions or perceptions of both mothers and her families stating that colostrum or first milk that cames out is bad and dangerous for baby, baby need other fluids before breastfeeding, colostrum and breast milk alone are insufficient for the baby's needs, the baby is feeling cold at IMD and exhausted mother after delivery is in a situation that is not acceptable to perform IMD. The preparation of IMD is heavily influenced by socioeconomic status, culture, and norms that flourish among family members and community in general (Tamiru D et al, 2012).

This study is conducted at Grobogan regency. Grobogan is a rural regency considered to still have cultural influence with certain beliefs especially in pregnant mothers and have a low source of health information without involvement from health workers or other relevant organizations to the site (DHO, Grobogan regency Health Office, 2017). The low level of knowledge will contribute to the lack of motivation by the mother to perform IMD and provide exclusive breastfeeding to their babies. Mothers know what is best for their children and mothers will try to give their best from their knowledge (Sirajuddin S et al, 2013). Data from interviews with one of the staff at the Grobogan regency Health Office shows the total target number of pregnant women in 2018 is 23,868 . Other data related to breastfeeding state that, only $72.73 \%$ of newborn babies were given to their mother and encouraged by health worker to be breastfed after 1 hour of delivery prior to vitamins administrations, and rest time given with consideration of fatigue of the mother after normal delivery. In case of caesarean section births, newborn will be 
required to be kept in recovery room, separated from the mother. Data also records that no IMD procedure carried out in accordance with Standard Operational Procedure (SOP) that is less than 30 minutes to 1 hours following delivery. This implies that indicator of successful IMD preparation is intervened by other factors preventing IMD. Preliminary study conducted in 10 pregnant women at Grobogan regency showed that 6 pregnant women did not prepare for IMD, because they did not know what it was. They only knew that breastfeeding should be initiated as early as possible following delivery. Meanwhile, 4 others said that they were preparing for IMD by searching information through health workers in ANC at the health center or during the class session for pregnant women.

Failed IMD preparation is caused by several predisposing factors such as knowledge, attitudes, or self perceptions. Enabling factors include health facilities in community health centers and other health services and health regulations, especially for IMD. Supporting factors are supports from husband, family, friends and health workers, in the form of information and encouragement in preparations for IMD. But the preparation and IMD itself can be carried out if all parties work together thoroughly and commit. Considering above reasons, the purpose of this study is to find out and analyze factors influencing pregnant women in preparation of IMD in the Grobogan regency.

Method

This study is a quantitative study with cross-sectional design or one-time observation of both variables. Data were collected using questionnaires. Study was conducted in January 2019. The population is 716 pregnant women: 397 from Godong 1 health center and 319 from Godong 2 health center. The sample selection was conducted in sub-districts with the largest area, that is Godong Sub-District as it represents Grobogan regency. Sampling is by purposive sampling with regard to inclusion and exclusion criteria. Samples inclusion are pregnant women who carried out routine ANC at the Puskesmas or in the KIA room at Puskesmas Godong 1 and Godong 2. Based on calculations, sample sizes (n) is 85 . To anticipate the drop out the researcher will take 100 samples.

Analysis is using chi square test with consideration of categorical data. Analysis of $\mathrm{p}$ value was then compared with the level of error used, $5 \%$ or 0.05 with the provisions that if $\mathrm{p} \leq 0.05$ then $\mathrm{H} 0$ is rejected which conclude that there is a significant relationship. Bivariate analysis was performed to determine the relationship between independent and dependent variables. Then, the independent variables that have a significant relationship with the dependent variable are included in the multivariate analysis, while variables that are not significant in the relationship are not included. To see factors that influence preparation of IMD in pregnant women, a statistical test with multivariate analysis is performed. We used multiple logistic regression to find out which variables or factors that have the greatest influence and analyze the effect of independent variables by considering confounding variables. Multivariate analysis is also conducted to analyze the effect of the independent variables together on the dependent variable and predict the dependent variable whether there is a change between the independent variables (Hadi S, 2015).

\section{Results and Discussion}

Univariate analysis will illustrates the frequency distribution of independent variables such as knowledge, attitudes, beliefs, support of husband/family, counseling during pregnancy, support of health workers and confounding variables including the characteristics of respondents such as age, occupation, education, parity, experience of IMD, and participation in classes of pregnant women. The dependent variable is the practice of pregnant women in the preparation of IMD.

Respondents in this study were mainly $\geq 20$ years old with $47 \%$ of respondents work as IRT (Housewife), 39\% as entrepreneur, $8 \%$ as civil servants/TNI/POLRI, $2 \%$ as farmers and the rest $4 \%$ as unemployed. Education background of respondents are the following: $63 \%$ from high school/vocational education, $28 \%$ from junior high school, while $9 \%$ from tertiary education. Based on observations, $70 \%$ of IMD preparation can be seen in group with 
parity/experience of breastfeeding/previous pregnancy delivery/have more than 1 child, while $30 \%$ of them are undergoing their first pregnancy. As many as $55 \%$ of respondents never perform IMD either primiparous or multiparous while $45 \%$ of them already perform at least once. Based on the attendance of pregnant women class, $84 \%$ of respondents did not attend the class, and only $16 \%$ attended the class.

Table 1. Frequency Distribution of Pregnant Women Characteristics

\begin{tabular}{|c|c|c|c|}
\hline No. & Characteristics & $\mathrm{N}$ & $\%$ \\
\hline 1. & $\begin{array}{l}\text { Age } \\
\geq 20 \text { years }\end{array}$ & 100 & 100 \\
\hline 2. & $\begin{array}{l}\text { Occupation } \\
\text { a. Unemployed } \\
\text { b. Entrepreneur } \\
\text { c. PNS/TNI/POLRI } \\
\text { d. Farmer } \\
\text { e. Housewives }\end{array}$ & $\begin{array}{l}4 \\
39 \\
8 \\
2 \\
47\end{array}$ & $\begin{array}{l}4 \\
39 \\
8 \\
2 \\
47\end{array}$ \\
\hline 3 & $\begin{array}{l}\text { Education } \\
\text { Middle High School } \\
\text { Senior High/Vocational } \\
\text { School } \\
\text { Tertiary }\end{array}$ & $\begin{array}{l}28 \\
63\end{array}$ & $\begin{array}{l}28 \\
63\end{array}$ \\
\hline 4. & $\begin{array}{l}\text { Pregnancy } \\
\text { a.First child } \\
\text { b.More than } 1 \text { children }\end{array}$ & $\begin{array}{l}30 \\
70\end{array}$ & $\begin{array}{l}30 \\
70\end{array}$ \\
\hline 5. & $\begin{array}{l}\text { IMD Experience } \\
\text { a. Never } \\
\text { b. At least once }\end{array}$ & $\begin{array}{l}55 \\
45\end{array}$ & $\begin{array}{l}55 \\
45\end{array}$ \\
\hline 6 & $\begin{array}{l}\text { Pregnancy Class } \\
\text { a. Not attend } \\
\text { b. Attend }\end{array}$ & $\begin{array}{l}84 \\
16\end{array}$ & $\begin{array}{l}84 \\
16\end{array}$ \\
\hline
\end{tabular}

Source: Primary Data, 2019

Age of mothers is related to the ease of a mother in understanding all information given regarding IMD. Older mother will have more level of maturity and power in thinking and working. Age is a predisposing factor that is likely to play a role in the preparation for Early Breastfeeding Initiation (IMD). In this study, pregnant women who came for the examination were mainly $\geq 20$ years old. Women who are in healthy reproduction age (safe age for pregnancy with low complication, delivery, and breastfeeding) is considered between 2035 years old. Women with age more than 35 years old will produce less hormones, resulting in decreased lactation. Women under 20 years old have less prepared physical, psychological, and social development that can interfere with psychological balance, affecting the preparation of IMD and the production of breast milk. Mothers who is breastfeeding should get adequate nutritional supplement food (Astuti I, 2013).

It is possible for mother that works outside to have more opportunities in accessing information about exclusive breastfeeding and IMD. Either way mothers who work as housewives are also capable to access more information by participating in activities such as classes for pregnant women or through midwives/health workers home visits.

Education can affect mother's reception of a new information. Mothers with relatively higher education have more open mindset and quick understanding of an explanation. Our results showed majority of mothers have high school/vocational education. High school/ vocational education is considered sufficient for respondents to deepen their understanding by searching information about IMD through sources such as books and the internet (Sirajuddin S et al, 2013).

Parity status in pregnancy may influence the mother's decision to make IMD preparation. Primiparous mothers tend to have less knowledge and experience and require support from families, midwives, doctors and other health workers. In contrast, multipara mothers have accumulated experience and information regarding IMD from health workers and families during previous pregnancy while setting aside whether they perform it or not (Walker M, 2008). The difference between primiparous and multiparous mothers does not guarantee multiparous mothers will successfully practice IMD. Parity does not have direct effect, but the experience of previous pregnancy will increase one's knowledge. A good experience from a first birth will form positive attitude and interest, empowering one's knowledge. Woman that successfully perform IMD will unconsciously prepare her own needs for the next IMD. Pregnant women who have never carried out IMD are given information from midwives or health workers to be able to prepare IMD by setting up equipment and adequate nutrition required for pregnancy. Mothers who have 
never had children are possible to perform IMD, while mothers who have given birth will have more information and experience about IMD (Rinata E, 2015).

Absence in class session are due to lack of awareness of the mother herself or lack of socialization from health workers in the vicinity. Things like this should no longer occur, given the importance of the program. Information obtained by researchers, health workers also utilized to revive the program but was hampered by the lack of government funding, that leads to inadequate pregnancy class to fulfill the necessary knowledge for pregnant mother.

The relationship between education and the practice of IMD preparation has a significance value of $0.412>0.05$, so there is no relationship between the education of pregnant women with the practice of IMD preparation. Pregnant women with low education (junior high school graduate) who did not prepare IMD were $53.5 \%$ and those who prepared were $46.4 \%$. Pregnant women who had high education (high school graduate and above) and did not prepare IMD were $44.4 \%$, and those who prepared IMD were $55.5 \%$. This study is in line with the results by Indramukti, 2013 which showed that there is no relationship between the level of education with the practice of Early Initiation Breastfeeding (IMD) in normal postpartum mothers in the working area ofthe Blado I Puskesmas in Batang Regency ( $\mathrm{p}$-value 1,000) (Indramukti F, 2013). In conclusion, a person without high education level can still make preparations for IMD because education is not only obtained in formal education, and pregnant women can actively participate in activities held by health centers around their homes such as attending classes for pregnant women and socialization at the time of examination pregnancy at the community health center or midwife.

The study results of the relationship between knowledge and practice of IMD preparation has a significance value of $0.488>$ 0.05 , meaning there is no relationship between the knowledge of pregnant women with IMD preparation practice. Then the knowledge of pregnant women who lacked and did not prepare IMD was $66.6 \%$, and those who prepared it were $33.3 \%$, while the knowledge of pregnant women who did not prepare IMD was $46.3 \%$, and those who prepared IMD were $53.6 \%$. These results are in line with the results of research in Vietnam by Le, et al, 2015 that there is no relationship between knowledge and IMD implementation, the results show that $13 \%$ of pregnant women who have high knowledge but have a negative attitude towards IMD. IMD practices are not always influenced by knowledge but there are several other factors such as pregnant women being influenced more by the opinions of families compared to their own knowledge. In other words, mothers actually have sufficient knowledge about IMD preparation but are influenced by the believe and knowledge of the family not to carry out the preparation (Le $\mathrm{N}$ et al, 2015; Kornides M and Kitsantas P, 2014).

In this study, the level of knowledge was measured using a questionnaire consisting of 10 questions namely about the definition of IMD, the benefits of IMD, colostrum and its benefits, as well as knowledge about the preparation of IMD itself. $52 \%$ of mothers answered the questions correctly, but they did not prepare for IMD. So that good knowledge cannot be categorized as having a significant influence on the practice of IMD preparation.

The results of the study showed the relationship between the attitude and practice of IMD preparation has a significance value of $0.932>0.05$ which means there is no relationship between the attitude of pregnant women with the practice of IMD preparation. Then the attitude of pregnant women who did not support and did not prepare for IMD was $46.5 \%$, and those who prepared it were $53.4 \%$, while the attitude of pregnant women who supported and did not prepare IMD was $47.3 \%$, and $52.6 \%$ who prepared for IMD. These results are in line with the results of the Fauziah, 2009 study which has a statistical test result $p=0.692$ that means there is no significant relationship between pregnant women who have positive attitude with IMD, 59.7\% of pregnant women have a positive attitude towards IMD practices but not much different from negative attitudes. According to the analysis, health workers play a role in shaping the attitude of pregnant women to prepare for IMD but pregnant women lack 
the response to the implementation of IMD practices. Attitudes describe a person's likes or dislikes towards objects. Attitudes make someone approach or avoid other objects. In general, a positive attitude will support good behavior as well. Attitude is a reaction or response that is still closed from someone to the stimulus or object, so it has not automatically materialized in an action (Anjarsari L, 2017).

In this study, the positive attitude of pregnant women in preparing for IMD is 57\% compared to the negative attitude of preparing and not preparing for IMD there were $43 \%$. Negative attitudes of respondents towards the implementation of IMD is because of the limited knowledge of respondents about the benefits of IMD so that mothers tend to give an unfavorable response to the IMD for that, increased socialization and counseling to mothers need to be increased so that their knowledge and understanding will develop so that it will provide a positive response to IMD implementation.

The study showed the relationship between believe and practice of IMD preparation has a significance value of 0.001 $<0.05$, then the confidence of pregnant women with IMD preparation practice is significantly related. Beliefs of pregnant women who did not support and did not prepare IMD were $72.4 \%$, and those who prepared were $27.6 \%$, while the beliefs of pregnant women who supported and did not prepare IMD were $36.6 \%$, and $63.4 \%$ who prepared IMD . In this study, factors related to IMD preparation are Believe. In this study, mothers did not believe that early breastfeeding initiation was something that had to be specially prepared, they only prepared baby and maternal equipment without preparing anything specifically for the implementation of the IMD. Other research in Lebanon shows that $24 \%$ of 353 pregnant women have the belief that breastfeeding can transmit the disease to infants, in this study health workers will make every effort to provide counseling in accordance with local beliefs and culture about IMD and exclusive breastfeeding (Osman H, 2009 ). In this study, mothers have the belief that IMD preparation does not need to be done because it is the duty of health workers in the hospital so that mothers do not need to be involved. One of the IMD preparations that mothers need to do is consult with health workers and cadres, but mothers have the belief that health workers should go to pregnant women who then provide counseling.

The study showed the relationship between breastfeeding experience / parity with IMD preparation practices has a significance value of $0.631>0.05$ meaning there is no relationship between breastfeeding experience / parity of pregnant women with IMD preparation practices. The experience of breastfeeding in the first child of pregnant women did not prepare IMD as much as $43.3 \%$, and those who prepared were $56.6 \%$, while the experience of more than one child who did not prepare IMD was as much as $48.5 \%$, and those who prepared IMD were $51.4 \%$. These results are not in line with the study of Nicole M. Hackman, et.al which shows that multiparous mothers have a significant relationship in IMD $(p=0.006)$ compared to primipara. This study, shows that pregnant women are given support to target improvements in IMD preparation practices and increase exclusive breastfeeding (Nicole M H, 2015). The results showed that multiparous mothers more indirectly did IMD preparation even though the significance results were not related.

The results of the study the relationship between husband / family support and IMD preparation practices have a significance value of $0.089>0.05$, then there is no influence between husband / family support for pregnant women with IMD preparation practice. Support for husband / family of pregnant women who did not support and did not prepare the IMD as much as $59.3 \%$, and those who prepared were $40.6 \%$, while the support of the husband / family of pregnant women who supported and did not prepare the IMD were $41.1 \%$, and who prepared IMD was $58.8 \%$. This is in line with the research of the Pertiwi, 2017, which obtained a statistical test result of $0.115>0.05$. There was no significant relationship between husband / family support, but the descriptive results stated that $60 \%$ made IMD preparation received husband / family support compared to those who did not get support at $40 \%$ (Pertiwi, 2017).

The absence of a relationship between 
husband / family support in this study can be caused by pregnant women getting positive support but for the practice of carrying out pregnant women still do it themselves by not ignoring advice from their husband / family. Because the results of existing studies show that with positive husband / family support, the practice of IMD preparation remains a reference for implementing IMD practices. Husband's support should not only be done during the preparation of the IMD, but it is very necessary to get the mother during the process of giving birth until the implementation of the IMD which is then followed by exclusive breastfeeding until the 6-month-old baby is now known as breastfeeding father. The importance of breastfeeding father greatly influences the success of IMD and exclusive breastfeeding.

The study showed the relationship between the participation of pregnant women in the class of pregnant women with the practice of IMD preparation has a significance value of $0.419>0.05$ meaning there is no relationship between the participation of pregnant women in the class of pregnant women with the practice of IMD preparation. Mothers who did not join the class of pregnant women did not prepare IMD as much as $45.2 \%$, and those who prepared were $54.7 \%$, while mothers who participated in classes of pregnant women who did not prepare IMD as many as $56.2 \%$, and those who prepared IMD were $6.25 \%$. These results are not in line with the study of Shalva Ismi, et al, 2016 which obtained the results of the analysis of the significance value of $\mathrm{p} 0.000<0.05$, which means there is a significant influence between the participation of pregnant women classes on IMD preparation and exclusive breastfeeding. Basically the class of pregnant women is very useful for pregnant women and their husbands / families, in these activities pregnant women get knowledge of pregnancy, IMD, childbirth, exclusive breastfeeding and baby care. In this case, IMD preparation is the main thing in the success of exclusive breastfeeding, so that if it is not optimal, health workers must make various efforts to improve the pregnant mothers class program (Shalva ismi et al, 2016; Shohifah P, 2016).

The results of the study the relationship between the role of health workers and the practice of IMD preparation has a significance value of $0.871>0.05$ meaning there is no influence between the role of health workers in pregnant women with the practice of IMD preparation. Health workers who did not play a role in pregnant women in IMD and did not prepare IMD were $45.9 \%$, and those who prepared were $54 \%$, while health workers who played a role in IMD and did not prepare IMD were $47.6 \%$, and those who prepared IMD were $52,3 \%$. The results of the study are in line with the results of the Hajijah study, 2012 which has a statistical test result of $0.085>0.05$ which shows there is no relationship between health workers and IMD preparation practices, whereas IMD is the beginning of exclusive breastfeeding practices that may or may not work. Another limitation factor is that health workers have limited knowledge about the practice of IMD preparation so counseling or counseling to pregnant women is less than optimal (Irawan J, 2018). The success of the IMD preparation practice lies in the role of health workers who should monitor from the beginning of pregnancy until delivery by giving regular counseling to pregnant women.

Multivariate analysis was used to find out which variables most influenced the practice of pregnant women in IMD preparation. The analysis used is multiple logistic regression.

\begin{tabular}{|c|c|c|c|c|}
\hline No & $\begin{array}{l}\text { Independent } \\
\text { Variable }\end{array}$ & $\mathrm{R}$ square & $\begin{array}{l}\text { Sig. } \\
\text { Anova }\end{array}$ & Sig \\
\hline 1 & Education & & & 0.345 \\
\hline 2 & Knowledge & & & 0.851 \\
\hline 3 & Attitude & & & 0.783 \\
\hline 4 & Believe & & & 0.001 \\
\hline 5 & $\begin{array}{l}\text { Breastfeeding } \\
\text { / parity } \\
\text { experience }\end{array}$ & 0.153 & 0.048 & 0.734 \\
\hline 6 & $\begin{array}{l}\text { Husband / } \\
\text { family support }\end{array}$ & & & 0.184 \\
\hline 7 & $\begin{array}{l}\text { Participation } \\
\text { in classes } \\
\text { of pregnant } \\
\text { women }\end{array}$ & & & 0.854 \\
\hline 8 & $\begin{array}{l}\text { Health workers } \\
\text { participation }\end{array}$ & & & 0.259 \\
\hline
\end{tabular}

Source: Primary Data, 2019 
Table.2 shows that the results of multivariate analysis contained 1 (one) variable, namely believe that influenced the practice of pregnant women in the preparation of IMD which had a significance value of $0.001<0.05$. These results also mean that all independent variables affect the dependent variable as indicated by the value of $r$ square $0.153(15.3 \%)$ the rest $(100 \%-15.3 \%=84.7 \%)$. The sig anova value also indicates that the independent variables influence together the dependent variable with a value of $0.048<0.05$.

The implementation of IMD in Indonesia is often done not according to the procedure, the IMD is done after the baby has finished taking care measures such as being cleaned, given vitamins and in a swaddled condition so that skin contact does not occur with the mother, often even the officer helps breastfeed the baby to the mother, because the baby is unable to find the mother's nipples. The correct implementation of IMD and according to the IMD procedure, by not skipping the baby's skin contact process with the mother, is proven to help bonding and subsequent breastfeeding (Mahmood I et al, 2011). This research is focused on how pregnant women prepare for IMD, understanding the importance of IMD in newborns becomes a necessity for all health workers and the wider community, especially pregnant women, as well as people's perceptions and opinions that are wrong about IMD also hinder success of this government program, so that the correct information about the IMD program should continue to be disseminated to the wider community so that the objectives of this government program can be achieved properly.

In this study, believe is the only factor influencing the preparation of IMD. Mother's believe related to the practice of preparing for early breastfeeding at the research site is possible because mothers still believe the myths about breastfeeding even though mothers have been given education through counseling during pregnancy checkups and during pregnancy classes for mothers about the importance of early breastfeeding initiation each month by village midwives. Different cultures in each region and different health behaviors. Culture consists of various aspects, one of which is believe. Believe is something that someone believes because it is passed down from parents to their children so that it becomes a fundamental behavior. Believe is a person's family members' beliefs starting from parents who believe in something and that is also believed by the surrounding community which is used as the basis for carrying out activities. For example, a belief that says that a new mother is still in a weak condition that requires adequate rest after giving birth and does not allow early breastfeeding initiation. Community beliefs that do not allow mothers to breastfeed before the breast and baby are cleaned. Preparation for early breastfeeding initiation has begun to be done and breastfeeding is common, but there are also those who believe that colostrum is not good for babies, which is marked by infant illness or in other words breastfeeding can transmit certain diseases so it is dangerous to do (Mamonto, 2015 ).

\section{Conclusion}

The study concluded that there was no relationship between education ( $\mathrm{p}$-value $=$ $0.412)$, knowledge $(\mathrm{p}$-value $=0.488)$, attitude $(\mathrm{p}$-value $=0.932)$, breastfeeding $/$ family experience $(p$-value $=0.631)$, husband's support $/$ family ( $\mathrm{p}$-value $=0.089$ ), participation in classes of pregnant women ( $\mathrm{p}$-value $=0.419)$, and the role of health workers $(p$-value $=0.871)$ with IMD preparation practices. Multivariate analysis test results of independent variables jointly affect the dependent variable, it is like the results of the regression with a significance value of $0.048<0.05$ of $0.153(15.3 \%)$ the rest $(100 \%-15.3 \%=84.7 \%)$ the practice of IMD preparation is influenced by other variables that are not examined, while the variable that most influences the IMD preparation practice is believe which has a significance value of 0.001 $<0.05$.

For health workers to improve the success of IMD preparation practices in pregnant women, it can be done by increasing counseling or counseling activities for pregnant women related to IMD, then the results of research in this thesis can be used as a basis or program evaluation related to IMD preparation practices for pregnant women, IMD practices during labor and exclusive breastfeeding. For pregnant women the success of IMD and 
exclusive breastfeeding is an important thing that is always socialized in the community, so expectant mothers are always responsive and pay attention to the information conveyed by health workers. Pregnant women are expected to independently always add information related to IMD and exclusive breastfeeding through socialization from health services, social media and other training. For other researchers, the results of this study can be used as reference material in further research on the practice of IMD preparation in pregnant women and can conduct research with wider variables and research locations and methods of collecting objective data and standardized questionnaires that have been modified as needed.

\section{References}

Acharya P, Khanal V., 2015. The effect of mother's educational status on early initiation of breastfeeding: further analysis of three consecutive Nepal Demographic and Health Surveys. BMC Public Health, 1069:15

Anjarsari, L., 2017. Hubungan Dukungan Keluarga Terhadap ASI Eksklusif Dengan Pemberian MP-ASI Pada Ibu Bekerja Di Desa Rembes Kecamatan Bringin Kabupaten Semarang. [Skripsi]. Semarang : Fakultas Kedokteran Universitas Diponegoro.

Astuti, I., 2013. Determinan Pemberian ASI Eksklusif Pada Ibu Menyusui. Jurnal Health Quality, 4(1): 1 - 76.

Bbaale,E., 2014. Determinants of earl initiation, exclusiveness, and duration of breastfeeding in Uganda. Int Cent Diarrhoeal Dis Res, 32(2): 249.

Dinas Kesehatan Kabupaten Grobogan., 2017. Profil Kesehatan Kabupaten Grobogan Tahun 2017.

Esteves,T. M. B., Daumas,R. P., Oliveira, M. I, Andrade, C. A, Leite, I. C., 2014. Factors associated to breastfeeding in the first hour of life: systematic review. Rev Saude Publica, 48(4): 697-708.

Hadi, S., 2015. Statistik. Yogyakarta:Pustaka Pelajar. Indramukti,F., 2013. Faktor Yang Berhubungan Dengan Praktik Inisiasi Menyusu Dini (IMD) Pada Ibu Pasca Bersalin Normal. Unnes Journal of Public Health, 3(2): 8-17.

Irawan,J., 2018. Hubungan Inisiasi Menyusu Dini (IMD) dengan Pemberian ASI Eksklusif di RSUD Wangaya Kota Denpasar. Skala Husada 15(1): 1 - 7

Kementrian Kesehatan RI.2015. Profil Kesehatan Indonesia tahun 2016. Sekretariat Jenderal.
Jakarta

Kornides, M., dan Kitsantas, P., 2014. Evaluation of breastfeeding promotion, support, and knowledge of benefits on breastfeeding outcomes. J Child Health Care, 17(3): 264-273

Le,N., Deoisres,W., \& Siriarunrat,S., 2015. Factors associated with breastfeeding initiation among postpartum mothers in Thai Nguyen Hospital Vietnam. Journal of Nursing Science and Health, 38(2)

Liqian Q, Yun Z, Colin W, Andy H and Xing X., 2009. Initiation Of Breastfeeding And Prevalence Of Exclusive Breastfeeding At Hospital Discharge In Urban, Suburban And Rural Areas Of Zhejiang China. International Breasfeeding Journal: 4-1

Mahmood, I., Jamal, M., \& Khan, N., 2011. Effect of mother-infant early skin-to-skin contact on breastfeeding status: A randomized controlled trial. Journal of the College of Physicians and Surgeons Pakistan, 21(10), 601-605.

Mamonto T. 2015. Faktor-faktor yang Berhubungan dengan Pemberian ASI Eksklusif pada Bayi di Wilayah Kerja Puskesmas Kotabangun Kecamatan Kotabagu Timur. Jurnal Kesehatan Masyarakat UNSRAT, 1(1): 1-11

Nicole, M. H., 2015. Breasfeeding Outcome Comparison by Parity. Volume 10, Number 3

Noer, E. R., Siti Fatimah \& Roni A., 2011. Praktik Inisiasi Menyusu Dini dan Pemberian ASI eksklusif Studi Kualitatif pada Dua Puskesmas, Kota Semarang. Media Medika Indonesiana. 45(3): 144-150.

Osman,H., 2009. Cultural beliefs that may discourage breastfeeding among Lebanese women:a qualitative analysis. International Breastfeeding Journal, 4:12

Pertiwi, R., 2017. Hubungan Keikutsertaan Di Kelas Ibu Hamil Dan Dukungan Sosial Keluarga Dengan Perilaku Pemberian ASI Ekkslusif Di Wilayah Kerja Puskesmas Kedungmundu. Jurnal Kesehatan Masyarakat 5(4).

Pradany, Shohifah Putri., 2016. Hubungan Tingkat Kehadiran Ibu Di Kelas Ibu Hamil Dengan Pemberian ASI Eksklusif. Jurnal Kedokteran Diponegoro 5(4).

Rinata, E. 2015. Teknik Menyusui Yang Benar Ditinjau Dari Usia Ibu, Paritas, Usia Gestasi dan Berat Badan Lahir di RSUD Sidoardjo. Jurnal Midwiferia. 1(1): 51-59

Sirajuddin,S, Abdullah,T, \& Lumula,S.N., 2013. Determinan Pelaksanaan Inisiasi Menyusu Dini. Jurnal Kesehatan Masyarakat Nasional. 8 (3).

S. I. Nasution., N. I. Liputo., dan Mahdawaty., 2016. 
Faktor-Faktor yang Berhubungan dengan Pola Pemberian ASI Eksklusif di Wilayah Kerja Puskesmas Bungus Tahun 2016. Jurnal Kesehatan Andalas 5(3): 635-639.

Tamiru,D, Belachew,T, Loha,E, Mohammed,S., 2012. Sub-optimal breastfeeding of infants during the first six months and associated factors in rural communities of Jimma Arjo Woreda, Southwest Ethiopia. BMC Public Health,12:363.

Walker,M., 2008. Breastfeeding the late preterm infant. JObstetr Gynecol Neonatal Nurs,37(6): 692-701 